\title{
News, Notes and Queries
}

Mariscallanae, where incidentally his name is spelt 'Nisbett', states he was M.D. Aberdeen 1785 by letters of recommendation of Drs. Dickenson and Keith, M.R.C.S. Edinburgh 1786 , and practised in London.

Curiously, confirmation of this attribution came from an entirely unexpected source. In 1925 Sir Archibald Garrod published an article on Alexander Marcet in Guy's Hospital Reports, 75, 373-87, in which he quoted from $A$ picture, etc., and appended to the reference the following note: 'Published anonymously, but attributed to Nisbet.' As there was no indication that Garrod had done any historical research on the authorship of the book and as the text itself gives no hint - thus making it practically impossible to penetrate the author's anonymity other than by a chance find in a contemporary record such as Morison's Diary-we reasoned that he must have obtained his information from an Oxford source where he was then Regius Professor. Our search was quickly rewarded since in Kidd's Catalogue of the Works in Medicine and Natural History contained in the Radcliffe Library, 1835 (Oxford; for the University) the book is catalogued by author under 'Nesbit' [sic]. Dr. L. W. Hanson, Keeper of Printed Books, Bodleian Library, kindly informed us that in the Manuscript Accession Lists the book appears under $1817 / 18$ as 'Nisbet, Biography of the College of Physicians', but because the compiler of the Modern Card Catalogue of the Radcliffe Science Library could find no sources for this attribution $A$ picture, etc. is currently catalogued as anonymous.

From the evidence here brought to light Nisbet's authorship can now be generally acknowledged.

RICHARD HUNTER AND IDA MAGALPINE

\section{Book Revierws}

A History of Chemistry. J. R. Partington. (4 vols.) London: Macmillan \& Co., 1961. Vol. II, pp. 795, $3^{8}$ text illus. $£ 55^{5}$.

Ir must be said at once that the work under review opens up a new epoch in the writing of the History of Chemistry. The last two great landmarks in this field were the works by Hermann Kopp (4 vols., 1 843-7) and Paul Hoefer (2 vols., 1842-3; 2nd ed., 1866-9). Each of these is a classic in its own right, offering a delightful text for reading, studying and the tracing of sources. These illuminate the development of Chemistry and indeed our knowledge of matter and the natural philosophy that forms its background. Apart from these old and some more recent supplementary works on the history of alchemy there has been nothing to meet the demands of the scholarly and serious student. Nor has there been any competent collection, sifting and discussion of the extensive literature that has accrued since the days of Kopp. This we are now given in the work under review - to the extent of what may well be called a definitive and exhaustive treatment of the subject. There is, however, much more than this. What should we expect from a History of Chemistry? Surely in the first place a competent and critical census of the actual contributions of individual savants which in itself reveals the standard of chemical knowledge at a given time. Obviously only an authority on modern Chemistry equipped with the knowledge, aptitude and understanding of a historian can be equal to the task. In this respect the example of Kopp and Berthelot has been followed-and surpassed-by Partington. This 


\section{Book Reviews}

particularly applies to the stupendous biographical and bibliographical apparatus and its evaluation and integration with the analytical and descriptive part in Partington's text. Indeed, the apparatus contains the detailed description of many rare items unknown to Ferguson and Duveen - the authoritative bibliographers of Chemistry and Alchemy. It also applies to the convincing identification of the substances prepared by and known to individual savants - substances that are often masked by fantastic names and cyphers. Here we are presented with the results of many years' close detective work including attempts at reproducing step by step the complicated and often intentionally mysterious procedures of the ancients in the laboratory. The investigation of natural philosophy by savants of the past was not infrequently associated with or even actuated by non-scientific ideas belonging to a religious and philosophical cosmology. The scientific output of some of them impresses us as the by-product of a non-scientific 'synthesis'. The importance of this background to scientific endeavour in the past has been realized in recent times-but it is from specialist work on the savant as a whole rather than the history of an individual branch of science that we should expect any broad elucidation of this background and the emergence of scientific discovery from it. Yet Partington has given generous hints in this direction and through his exhaustive literary apparatus guides the reader desirous of relevant information to the appropriate sources. Nor would it be true to say that Partington has written a history of individual chemists rather than a History of Chemistry. It is true that his book consists of profound analyses of the savants in chronological order. He thus leaves it to the intelligent reader to form his own judgment on the standard of chemical knowledge in the various phases of the period treated. This should not be difficult, as the progress reached by the savant and his relationship to predecessors and followers is indicated with singular clarity. Indeed, Partington's method would appear to be far superior to the provision of a distilled 'story'-the facile essay that is of necessity selective and coloured by personal idiosyncrasies on the part of the author.

The work is intended to cover the whole of the History of Chemistry from the earliest times up to the present in four volumes. The volume under review is the second, devoted to the period from 1500 to $1700-$ embracing such decisive figures in the History of Chemistry as Theophrastus Paracelsus (1493-1541), Vanoccio Beringuccio (1840-1 538), George Agricola (1494-1555), Jerome Cardan (I50I-76), Lazarus Ercker (1 530-94), John Baptist Van Helmont (1579-1644), Andreas Libavius (I540I6I6), Thomas Willis (1621-75), John Rud. Glauber (1604-70) and above all Robert Boyle (I627-9I) and John Mayow (164I-79). It is the chapters on Boyle (63 pp.) and on Mayow (59 pp.) which form the climax of the work-based as they are on the definitive original and detailed research of the author. The work concludes with the Phlogiston theory (J. J. Becher, I635-82; G. E. Stahl, I66o-I 734), and with Friedrich Hoffmann (1660-1 742) and Herman Boerhaave (1668-1 738). The main landmarks thus are: an Empirical Prelude from Leonardo to Porta and the Books of Secrets, followed by the Technical Treatises from Beringuccio to Gesner, Palissy and the 'Distillers', Paracelsus and Iatrochemistry, Inventors and Theorists such as Drebbel and Kircher, Glauber and Kunckel, the Revival of Atomism with Boyle, and the Phlogiston Theory. In addition there are extensive chapters on Sir Francis Bacon, on Gassendi, Descartes and Newton and a multitude of 'smaller' men who influenced chemistry in some way, mostly indirectly. Here Partington has cast his net wide-including such obscure and hardly known figures as Hautnorthon or such rare and small tracts of chemical recipes as the Rechter Gebrauch d'Alchimei of $153 \mathrm{I}$-to quote only two examples 


\section{Book Reviews}

out of a thousand others. William Davidson ('Davisson') of Aberdeen (I593-1669) may be missed, although he may be conveniently discussed alongside of Beguin-one of the dramatis personae promised for the subsequent volume. The medical historian will welcome the many hints given as to the impact of chemical discoveries on physiology and medicine, for example in the chapters on Paracelsus and Van Helmont, although perhaps more might have been said on Van Helmont's merits in the discovery of acid digestion (and his implicit knowledge of the role of hydrochloric acid therein) in the discussion of Van Helmont himself. Violet (1635) is rightly accepted as a source for the knowledge of acid digestion intermediate between Paracelsus and Van Helmont. It would appear to the reviewer, however, that Violet in turn depends upon Duchesne (Quercetanus $1544^{-1609)}$ who already in 1603 shifted the emphasis from the Galenic heat to the acidity of a 'vitriolate fire' or sharp humour in the stomach presumably of all animals and man, as against Paracelsus who had limited it to certain animals such as the ostrich (see Quercetanus De Priscor. Philosoph. Verae Medicinae Materia, tract II, ed. Col. Allobr. I609, pp. I 10-12; Practise of Chymicall and Hermeticall Physicke, tr. T. Timme, London 1605 , sig. L2 recto, I. I-5 from: Ad Veritatem Hermeticae Medicinae Paris I604, p. 230). Perhaps Quercetanus and other Paracelsists (including even H. Khunrath) merit more study than is usually accorded to them by historians of chemistry and medicine. Van Helmont is chiefly remembered today as the discoverer of Gas, and Partington beautifully elucidates the specific character of the gases described by Van Helmont and identifies them chemically, thereby establishing their correct place in the history of chemistry. It may be added that Van Helmont seems to have understood by Gas not only a limited number of entities which can be identified in chemical terms today, but generally that which gives any object in nature its specific stamp. It can be visualized in the test tube when its coarse material cover is removed by combustion-Gas being the object itself or at any rate all that really matters in it. This interpretation, however, may be rightly said to transcend the confines of the History of Chemistry proper. Partington fully recognizes the influence of Van Helmont on Boyle who, he says, was 'in many ways . . . anticipated by Van Helmont whose works he studied with care and to whom he frequently refers as an authority'. Indeed, Boyle could have hardly failed to be impressed by the strong body of 'Helmontians' among his countrymen at the time, and it might even be rewarding to study in connection with Boyle certain Paracelsian ideas: for example, that Life is a process of combustion-'if I say it cannot burn this is as much as if I said it cannot live'; and, 'In the air is the force of all life' (Paracelus, Liber Azoth, ed. Sudhoff, vol. xIv, pp. 549-58; see also Ambix 196o, vir, p. 1 50). It is also in connection with air that we find in the same Paracelsian book life characterized as spirit of nitre and are thus reminded of the nitro aerial particles of Mayow.

No word of praise can do justice to the thoroughness and completeness of the work under review, to the wealth of original and profound research that has gone into it, to the new aspects which it opens up and to the soundness of critical judgment which it displays. The work ranks with such literary and historical beacons as Zeller's Philosophie der Griechen, Haeser's Geschichte der Medizin, Sir Clifford Allbut's Greek Medicine in Rome, Sarton's Introduction and Thorndike's History of Magic and Experimental Science. Since the days of Paracelsus physicians had to reconcile themselves to the fact that the essence of medicine is chemistry-obviously then the serious historian of medicine will join his chemical colleague in basing much of his reading, research and tracing of sources on Partington's new classic.

WALTER PAGEL 